Watt, Garfield, etc. All the stories are brief, true, pointed. The boy will be at once interested in them and life purposes will be cultivated. It is a book with a purpose and suited to the purpose. The illustrations make more vivid the narratives.

W. O. Carver.

\title{
An Introduction to the Bible for Teachers of Chil- dren. A Manual for Use in the Sunday Schools or in the Home.
}

By Georgia Louise Chamberlin. With an Introduction by the Editors. Constructive Bible Studies, Elementary Series. Chicago, The University of Chicago Press, 1904. Pages xxxviii., 206. Price \$1.00.

In the introduction the editors say, "The present volume, prepared in the laboratory of the actual class-room, is intended as the text-book for the fourth grade. Following the work of the kindergarten and the three years in which the child is taught chiefly by means of Bible stories, this year's work is devoted to the important task of giving to the pupil a knowledge-correct, even though necessarily incomplete- of the contents of the Bible as a whole, creating in him a genuine interest in the books that make up the sacred collection." An examination of the book leads one to marvel that such difficult lessons should be assigned to children under ten years of age, but the author's statement in the Preface seems to imply that the lessons were prepared for the seventh grade and for children from ten to twelve years of age. The author has made a careful study of questions of date, authorship and historical value of the different books of the Bible, and has adopted the views commonly held by critics of the mediating school. The early narratives in Genesis are treated as "story-sermons," Deuteronomy as a rewriting of the law of Moses shortly before the reign of Josiah, the author of Jonah as perhaps the latest prophet of Old Testament times, etc.

The lessons presented in this book were worked out in 
three years of teaching successive groups of children in the same grade of the Sunday School of the Hyde Park Baptist Church, Chicago. The author recognizes the fact that her pupils were not such as the average teacher has to instruct, and that the conditions were ideal in many respects. Few teachers of the corresponding grade of pupils in other schools could hope to use successfully the lessons as here outlined.

The author displays skill in laying out work for teachers, and her suggestions as to the best method of presenting the lesson reveal a good knowledge of child nature. The effort to secure home work on the part of pupils and to enlist the aid of parents is very praiseworthy. Thoroughness is insisted upon. The book is worthy of a careful reading by both teachers and parents. Out of experiments such as this improved methods for the Sunday Schools of the world will be slowly evolved.

JoHN R. SAMpey.

\section{The Teaching of Jesus Concerning the Kingdom of God and the Church.}

By Geerhardus Vos, Ph.D.,D.D.

This volume is second in the series preparing under the editorship of Dr. John H. Kerr, for the American Tract Society.

The series is meant to be a popular course in Biblical Theology, setting forth "the teaching of Jesus" as to his own mission, his own person, God the Father, the Holy Spirit, the future life, etc.

Eminent scholars are engaged in the work. Prof. Vos has in this volume given us a presentation of conclusions supported by references to words of Jesus and defended by lines of argument. That his conclusions are in the main correct does not quite compensate for his failure to set before us more fully the Scriptures and allow us to travel with him the roads to his results. There is 